\title{
Critical Assessment of Smart City Mission - A Research of Gwalior Smart City Proposals
}

\author{
Mohd. Nasir, Mohammad Salman, Fahad Ahmad, Tahir Abdul Rahman Siddiquee
}

\begin{abstract}
Smart city mission aims to promote the quality life in Indian cities and for that cities were selected from entire India. All the smart cities needed to make a smart city proposal (SCP) for further selection. Gwalior is being selected to be one of the smart cities in 100 Indian cities. Gwalior is a city in Madhya Pradesh and had a strong link to the region glorious past, as this is the one of oldest center in region (as per the current footprints). Because of fast urbanization rate the current condition shows urban decay due to lacking in core infrastructural element in almost most all the Indian cities, Gwalior is also going through same issue. The paper aims to identify the various unexplored aspects that were not considered and not taken care of in the current SCP. This research work will be started with the understanding of the concept by analyzing the guidelines of the smart city mission and comparative study/analysis of smart city global module(international modules on smart city), the entire research work will focus to identify the gaps between need of the city and smart city proposal.

Keywords - smart city, smart city proposal,
\end{abstract}

\section{INTRODUCTION}

As the rate of urbanization growing faster from last century and in today's world it's at peak in human history and because of that population in cities increasing as per many studies and researchers expected that India's urban area going to cater $40 \%$ population of the total as urban population and to accommodate this big amount it requires to develop all infrastructure services through which a city be alive physical institutional, economic and social infrastructure in sustainability aspect as all the very important in improving quality of life

As per the smart city guideline the city which calls itself smart must having these core infrastructure elements:

- Adequate water supply,

- Health and education.

- Sanitation, including solid waste management,

- Efficient urban mobility and public transport,

- Affordable housing, especially for the poor,

- Robust IT connectivity and digitalization,

- Good governance, especially e-Governance and citizen participation,

- Sustainable environment,

- Safety and security of citizens, particularly women, children and the elderly, and

- Assured electricity supply,

Revised Manuscript Received on April 12, 2019.

Mohd. Nasir, SIGMA College of Architecture-Kanyakumari, T.N, India. (E-mail: abdulnsr201@gmail.com)

Mohammad Salman, Beary Enviro Architecture Design SchoolMangalore, India. (E-mail: ar.salman279@gmail.com)

Fahad Ahmad, CASA Forever Pvt. Ltd.

Aligarh, India. (E-mail: fahad.livestrong@ gmail.com)

Tahir Abdul Rahman Siddiquee, International Islamic University

Kuala Lumpur, Malaysia. (E-mail: tahir.aligarh89@gmail.com)
The concept of smart cities came forward with a vision of making the Indian cities more livable, sustainable and economically viable. This concept is further split up into two aspects i.e. the Area Based Development and the PAN city proposals. With the combination of both, the concept envisions to make the Indian cities smart

According to the proposals analyses, around (65-75\%) of the project funding will be spent on area based development and only3-4\% of the city population come under the direct benefit of it, because most of the projects under it are only like old center retrofitting/redevelopment in sense of beautification proposed in many SCPs and for entire city project comes under pan city scheme which deals only in limited field IT based services i.e. CCTV- monitoring center, educational portal, water and traffic management. this approach of prioritization might enhance a lived experience of residents fall under these area, but it poses larger questions mark on the vision of this mission as making whole city smart in current module' on the other hand there are multiple policies in existence for urban India: the Swachh Bharat the National Urban Livelihoods Mission; the National Urban Information System; and the Heritage City Development and Augmentation Yojana (HRIDAY). Additionally, there are multiple infrastructure projects like city roads expansion and highways, water reservoir and storage-related development which are mostly undertaken by development authorities or the State governments. The linkage between all these with smart city mission unknown and unconnected. Therefore, it is required to study/analysis to come up with a sustainable module which benefits maximum. The aim of this research is to analysis the current scenario-potential and issues of city and Gwalior smart city proposal(to find out gaps and need) and come up with proposal (solutions) and process to make it as (smart ) under guideline of smart city for sustainable development of city and communities.

\section{HISTROY BACKROUND}

Gwalior city is the third largest city of Madhya Pradesh, situated in the rich Chambal agro region. It was the capital of former state of scindhias. It comprises of three distinct settlements namely old Gwalior situated on the north of the fort hill, lashkar is in the south of old Gwalior and third settlement called morar cantonment in the east lashkar was developed during the British regime as cantonment. 


\section{CRITICAL ASSESSMENT OF SMART CITY MISSION - A RESEARCH OF GWALIOR SMART CITY PROPOSALS}

The city derived its name from historic fort hill called gopaparbat-gopadri, continued to grow and flourish around north and north east of fort hill, until during scindias regime. the early settlement being the capital of the state belonging to 6th century A.D. witnessed cheered history with the change of rulers often after feudal wars the town passed through many hands, who founded the fort to various to schindias in the recent past. During Mughal regime the city gained its fame in the music world when 16 of 36 famous musicians of Akbar durbar belong to Gwalior. It was only during scindhias regime that the foundations of new town away from old Gwalior were laid when maharaj daulatrao scindhia shifted his capital from Ujjain and setup a camp in this town in the area known as lashkar.

The British, in their set pattern developed cantonment away from the town in morar and neglected the development of town. The first municipality was established in 1887 with resulted in rapid development of the city in scindhias period. Post-Independence period witnessed the growth of the city as one of the principle educational center of the state.

Beside above, many new colonies came into existence, developed by private and government agencies.

\section{REGIONAL IMPORTANCE}

Gwalior is the largest city of Gwalior agro region the region consist of five district Gwalior, bhind, morena, datia and shivpuri. The city enjoyed the status of flourishing Centre for trade and commerce and since then its continuously growing to function as regional Centre. apart from this city also functions as important administrative Centre of region thus playing vital role in the economy of the region and occupies a place of regional city. City growth Trent-the earliest settlement of OLD Gwalior (gapura)came up and functioned as a link development to the fort on the hillock. The development in the lashkar started from camp and ultimately took the shape of a township. the development of morara also came for providing accommodations to military and administrative personnel. Natural land form have also played significant role in giving present urban form of city.

Gwalior is located in rock basin corresponding to vindhyan hills in the west and bijawar hills in the south east.These hill portions have given aesthetic frame to city urban forms. When we see further in detail we found Gwalior is situated between two natural divisions, namely the plain in north-east and hilly country in south east. The plains extended from the Chambal River in extreme north. the city lies in a horse shoe shaped valley surrounded on the three sides by low hills of vindhyan ranges.

\section{DEMOGRAPHIC PROFILE}

Gwalior Municipal Corporation, with population of about 11.7 lakh is Gwalior (Gird) sub district's only municipal corporation located in Gwalior (Gird) sub district of Gwalior district in the state Madhya Pradesh in India. Total geographical area of Gwalior Municipal Corporation is 413 $\mathrm{km} 2$. Population density of the city is 6157 persons per $\mathrm{km} 2$.There are 66 wards in the city, among them Gwalior Ward No 18 is the most populous ward with population of about 40 thousand and Gwalior Ward No 59 is the least populous ward with population of 9138 .
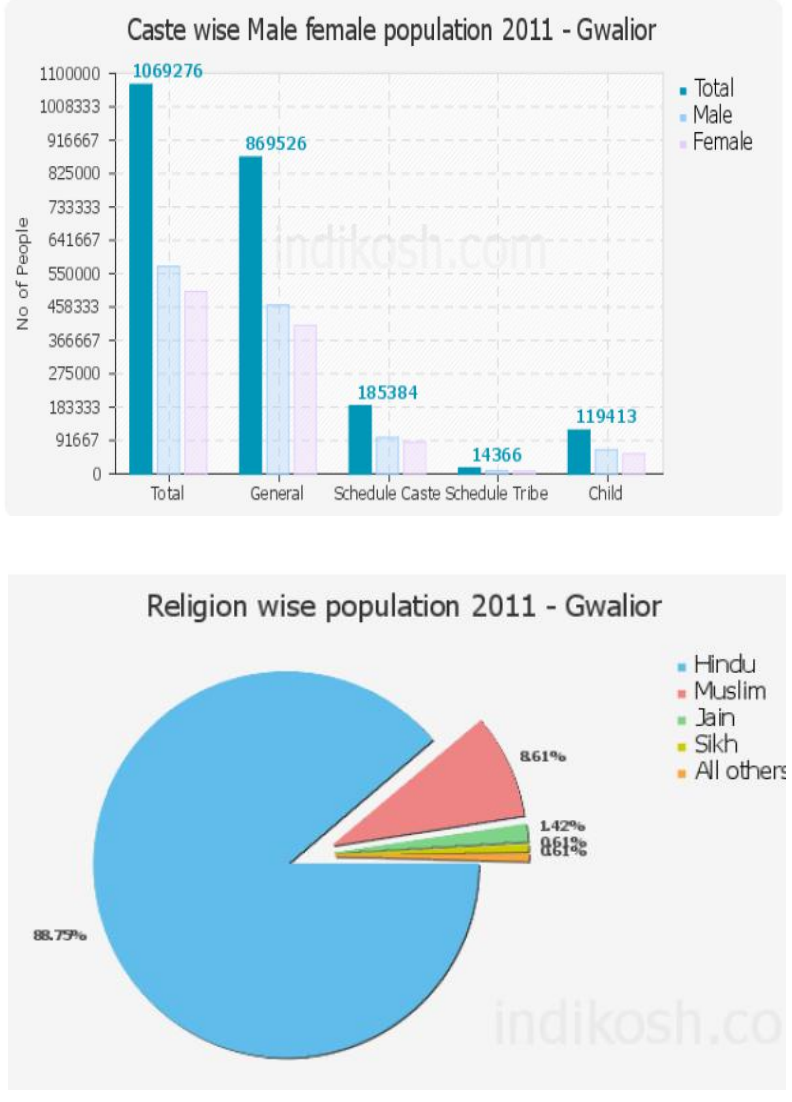

LITERACY

Out of total population.... 8 lakh(approx.) come under literacy graph in which around 3.5 lakh female and 4.5 lakh male (children under 6 are excluded).literacy rate is $84 \%$ in Gwalior in last decade survey (census) an growing trend is observed that male literacy rate is going down about $2 \%$ mean while female gone up $7 \%$.

\section{WORKERS PROFILE}

In Gwalior as per census 2011 about 3.3 lakh only (31\%) population engaged in either main or marginal works. $49 \%$ male and $10 \%$ female population working population for male population main (full time) workers are $45 \%$ of total and marginal (part time) workers are $4 \%$. For women female population main worker are $8 \%$ of total and $2 \%$ are marginal workers

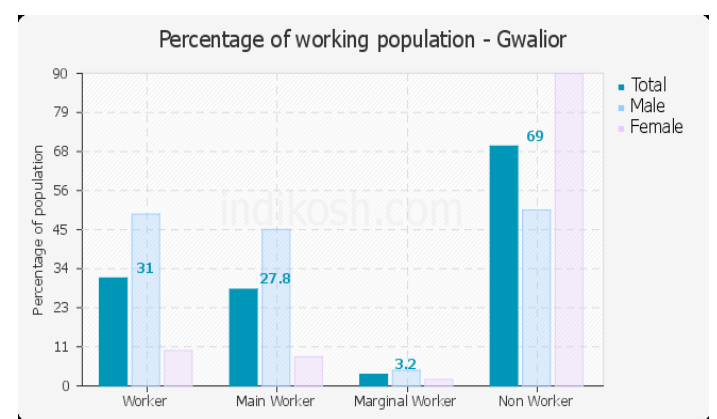

Published By: Blue Eyes Intelligence Engineering 


\section{TEST RESULTS}

The development in the three different periods gave a district physical shape of the city with three different townships of Gwalior, lashkar and morar. The open space left in between the townships was later on filled up by uncontrolled/co-ordinated manner and mixed development after independence.
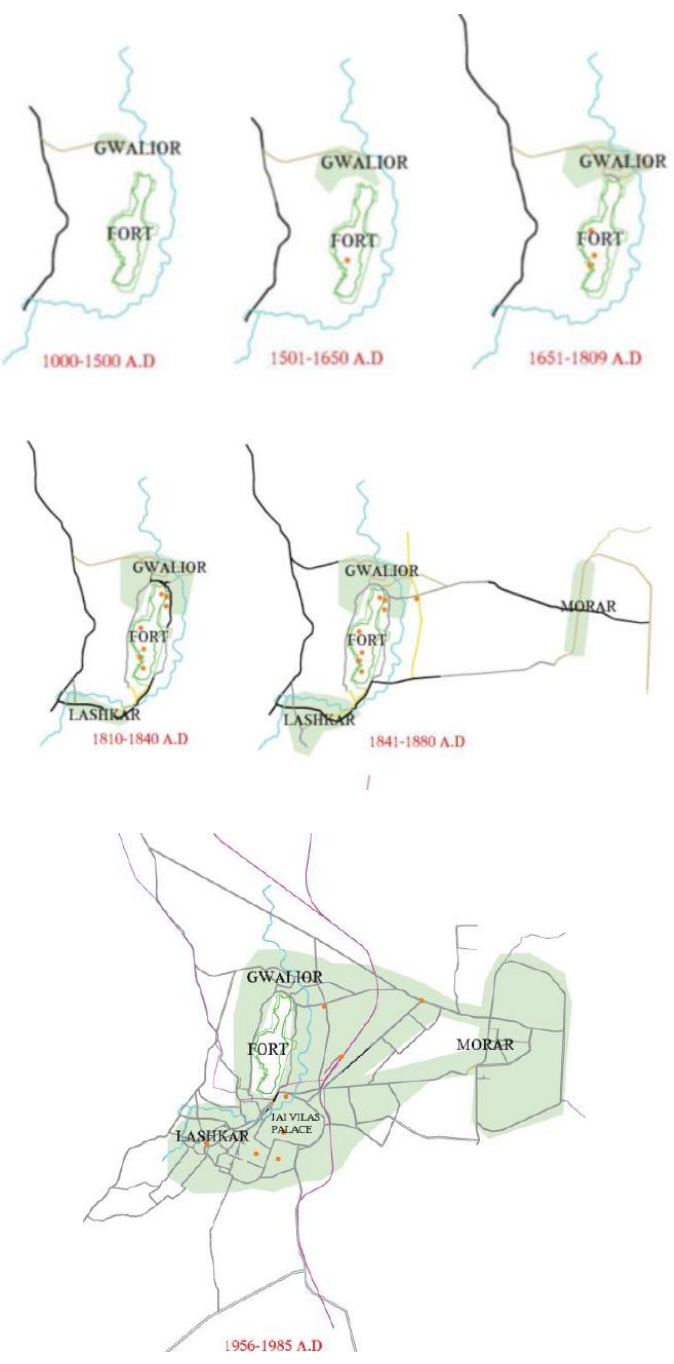
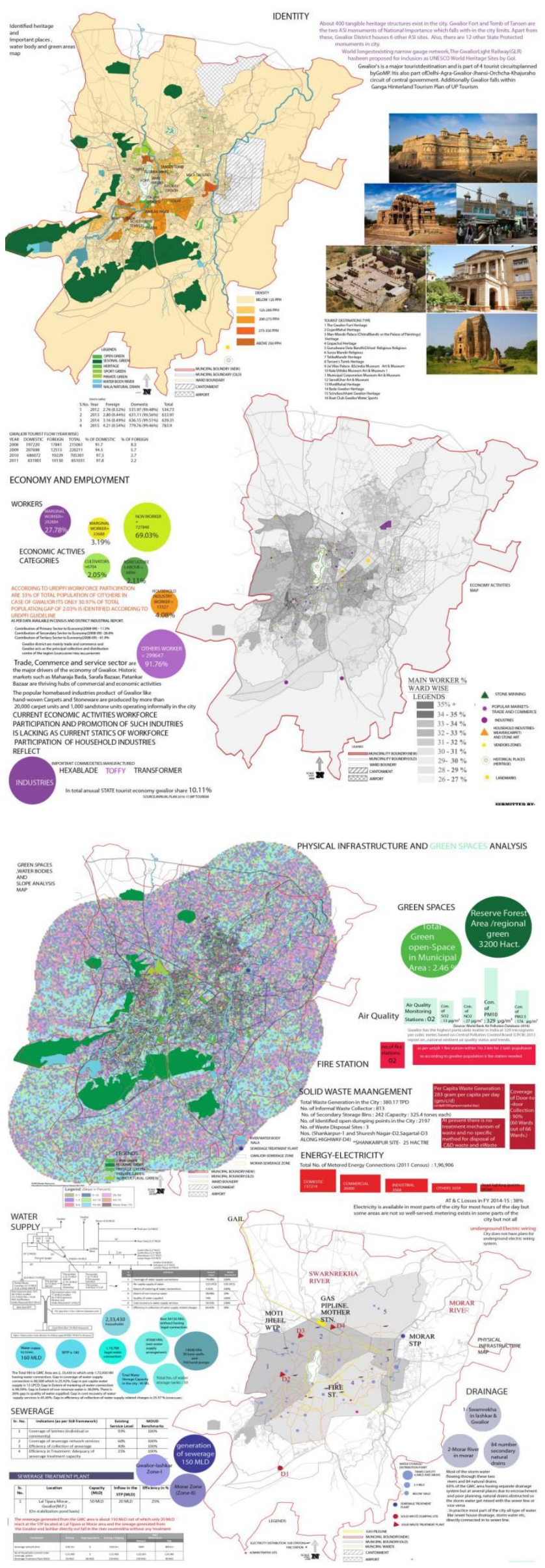

Published By:

Blue Eyes Intelligence Engineering

\& Sciences Publication

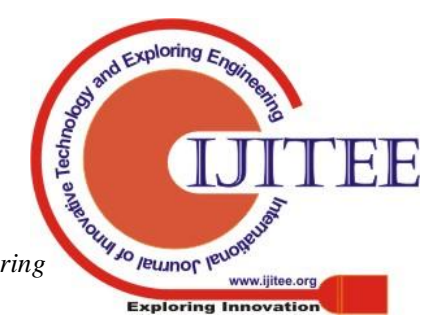




\section{CRITICAL ASSESSMENT OF SMART CITY MISSION - A RESEARCH OF GWALIOR SMART CITY \\ PROPOSALS}
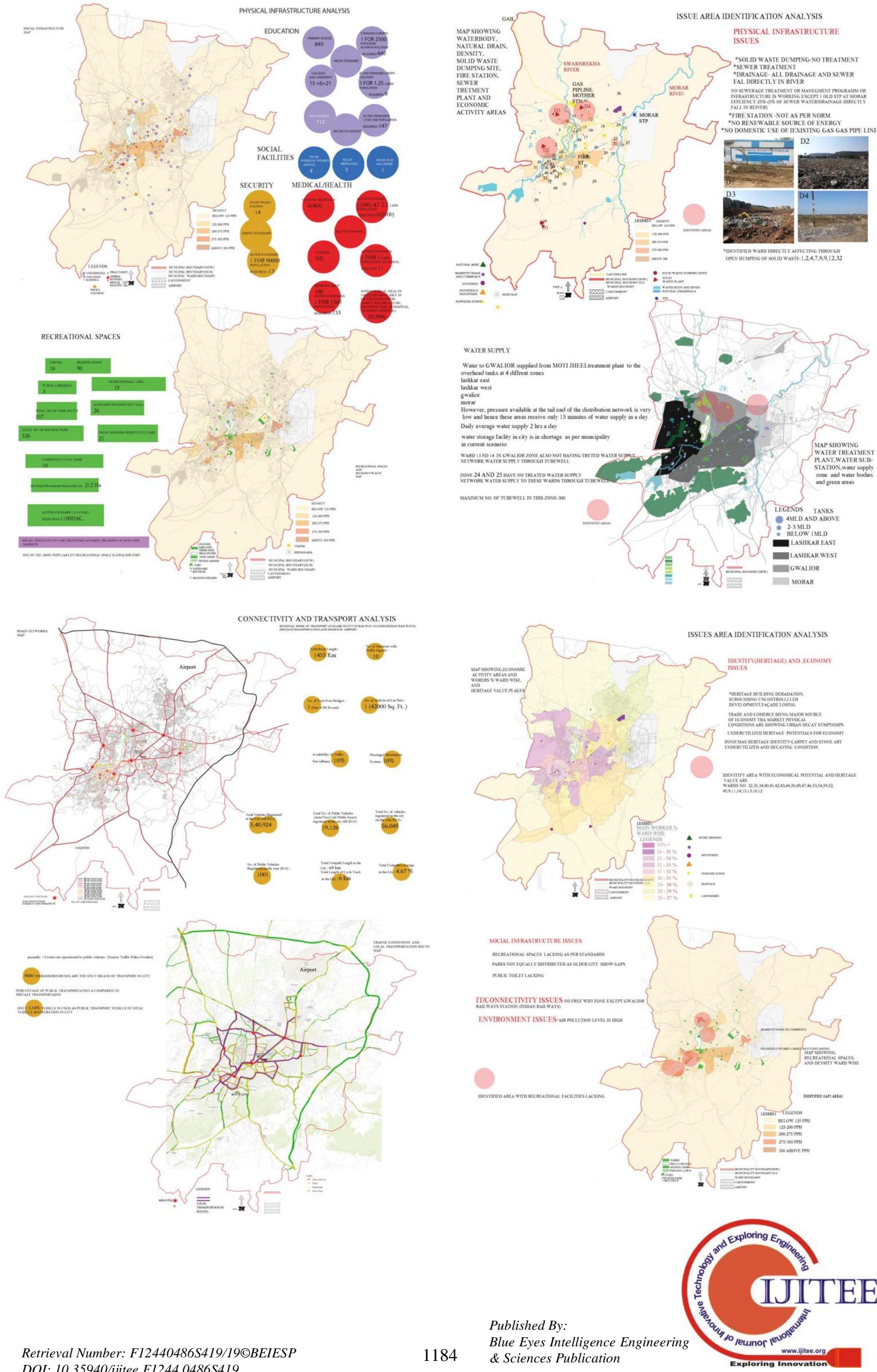

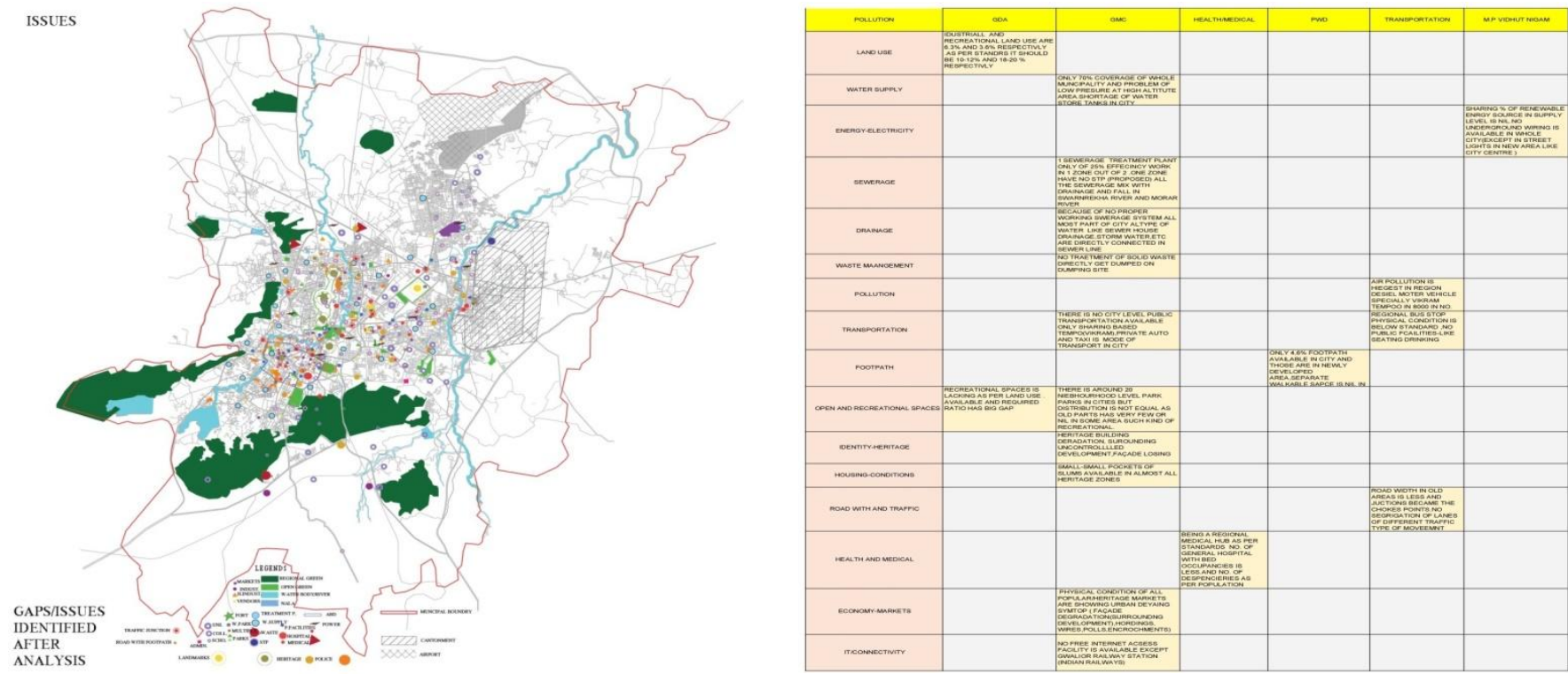

COMPARATIVE ANALYSIS OF CITY NEED AND CITY SCP'S

\begin{tabular}{|c|c|c|c|c|}
\hline $\begin{array}{l}\text { ISSUES/GAPS } \\
\text { IDENTIFIED }\end{array}$ & $\begin{array}{c}\text { CITY } \\
\text { AREAS(WARDS) } \\
\text { WITH PROBLEM } \\
\end{array}$ & $\begin{array}{c}\text { SMART } \\
\text { CITY - } \\
\text { ABD } \\
\text { COVERS/ } \\
\text { (AREAS) }\end{array}$ & $\begin{array}{l}\text { SMART CITY- } \\
\text { PROPOSALS }\end{array}$ & REMARKS \\
\hline $\begin{array}{l}\text { only } 70 \% \text { coverage of } \\
\text { whole municipality and } \\
\text { problem of mix of treated } \\
\text { and tubewell water supply } \\
\text { and problem of low } \\
\text { pressure at high altitude } \\
\text { area.Shortage of water store } \\
\text { tanks in city.and only 2-3 } \\
\text { hr. water supply in day }\end{array}$ & $\begin{array}{l}\text { All most all wards in } \\
\text { city have same problem } \\
\text { of water supply time } \\
\text { and mix of tube well } \\
\text { and treated water } \\
\text { supply and ward } 24 \text { and } \\
25 \text { have only tube } \\
\text { wellwater supply no } \\
\text { treated water supply in } \\
\text { these wards. }\end{array}$ & $\begin{array}{lr}\text { only } & 18 \\
\text { wards } & \text { out } \\
\text { of } & 66 \\
\text { wards } & \\
\text { lashkar } & \\
\text { east zone }\end{array}$ & $\begin{array}{l}\text { proposal for } 24 \times 7 \\
\text { water supply }\end{array}$ & $\begin{array}{l}\text { not solving the basic problem } \\
\text { of treated and untreated water } \\
\text { suply.only } 18 \text { wards get } 24 \mathrm{x} \\
7 \text { and no proposal for rest }\end{array}$ \\
\hline $\begin{array}{l}\text { sharing } \% \text { of renewable } \\
\text { energy source in supply } \\
\text { level is nil.no underground } \\
\text { wiring is available in whole } \\
\text { city(except in street lights in } \\
\text { new area like city centre ) }\end{array}$ & $\begin{array}{l}\text { all most all wards in } \\
\text { city have same problem } \\
\text { of water supply time } \\
\text { and mix of tube well } \\
\text { and treated water } \\
\text { supply and ward } 24 \text { and } \\
25 \text { have only tube } \\
\text { wellwater supply no } \\
\text { treated water supply in } \\
\text { these wards. }\end{array}$ & $\begin{array}{l}\text { one/two } \\
\text { public } \\
\text { institution }\end{array}$ & $\begin{array}{l}\text { roof top solar } \\
\text { panel installation }\end{array}$ & $\begin{array}{l}\text { there is no solid } \\
\text { prpoposal/plan for conversion } \\
\text { of conventional energy supply } \\
\text { to renewabale source of } \\
\text { energy suppply }\end{array}$ \\
\hline $\begin{array}{l}1 \text { sewerage treatment plant } \\
\text { only of } 25 \% \text { efficiency } \\
\text { work in } 1 \text { zone out of } 2 \text {.one } \\
\text { zone have no } \\
\text { STP(proposed) all the } \\
\text { sewerage mix with drainage } \\
\text { and fall in swarnrekha river } \\
\text { and morar river }\end{array}$ & $\begin{array}{l}\text { at Gwalior- lashkar } \\
\text { zone and half morar } \\
\text { area }\end{array}$ & nil & no proposals & $\begin{array}{l}\text { much needed proposal at city } \\
\text { level }\end{array}$ \\
\hline
\end{tabular}




\section{CRITICAL ASSESSMENT OF SMART CITY MISSION - A RESEARCH OF GWALIOR SMART CITY PROPOSALS}

\begin{tabular}{|c|c|c|c|c|}
\hline $\begin{array}{l}\text { no treatment of solid waste } \\
\text { directly get dumped on } \\
\text { dumping site }\end{array}$ & $\begin{array}{l}\text { wards } \quad \text { affected } \\
\text { directly(1,2,4,7,8,9,12,3 } \\
\text { 2) }\end{array}$ & pan city & $\begin{array}{l}\text { proposal for } \\
\text { picking waste and } \\
\text { collection only on } \\
\text { dustbin based } \\
\text { censor technology }\end{array}$ & $\begin{array}{l}\text { proposal needed for treatment } \\
\text { of solid waste }\end{array}$ \\
\hline $\begin{array}{l}\text { there is vikram tempo at } \\
\text { city level public } \\
\text { transportation available } \\
\text { only,private auto and taxi is } \\
\text { mode of transport in city }\end{array}$ & whole city & pan city & $\begin{array}{l}\text { proposal for public } \\
\text { transportation } \\
\text { network and } \\
\text { services, developme } \\
\mathrm{nt} \text { of } \\
\text { corridor,strengtheni } \\
\text { ng of existing } \\
\text { bridges on } \\
\text { swamarekhariver,p } \\
\text { edestrian only zone } \\
\text { at bada }\end{array}$ & $\begin{array}{l}\text { much needed proposal at city } \\
\text { level }\end{array}$ \\
\hline $\begin{array}{l}\text { Recreational spaces is } \\
\text { lacking as per land use. } \\
\text { available and required ratio } \\
\text { has big gap }\end{array}$ & whole city & $\begin{array}{l}\text { in } \quad 18 \\
\text { wards only }\end{array}$ & $\begin{array}{l}\text { improvement of } \\
\text { existing parks } \\
\text { (upgradation on } \\
\text { nehru park, ladies } \\
\text { park and shivaji } \\
\text { park)andrejuvenati } \\
\text { on and riverfront } \\
\text { development of } \\
\text { swamerekha river }\end{array}$ & $\begin{array}{l}\text { only } 1.6 \mathrm{~km} \text { of river get } \\
\text { dveloped }\end{array}$ \\
\hline $\begin{array}{lr}\text { heritage } & \text { building } \\
\text { degradation, } & \text { surrounding } \\
\text { uncontrolled } & \text { development, } \\
\text { façade losing } & \end{array}$ & $\begin{array}{l}\text { old Gwalior,Qilagate } \\
\text { area,jama masjid area } \\
\text { (wards- } \\
3,4,5,9,11,14,15) \text {,lashka } \\
\text { r(maharajbada)(wards- } \\
\text { 40-45,50,57) }\end{array}$ & $\begin{array}{l}\text { lashkar } \\
\text { (maharajb } \\
\text { ada) }\end{array}$ & $\begin{array}{l}\text { revitalizing } \\
\text { maharajbada and } \\
\text { heritage network } \\
\text { trail }\end{array}$ & $\begin{array}{l}\text { old gwalior,qila gate jama } \\
\text { masjid area and thatipur are } \\
\text { also need revetelization }\end{array}$ \\
\hline $\begin{array}{l}\text { small-small pockets of } \\
\text { slums available in almost all } \\
\text { heritage zones }\end{array}$ & $\begin{array}{l}\text { lashkar area(wards- } \\
32,34,35,39,40,44,48,53 \\
, 52,59,45,37), \text { old } \\
\text { Gwalior area } \\
(3,9,11,13,14,15,16) \text { and } \\
\text { morar(21,22) }\end{array}$ & $\begin{array}{l}\text { lashkar } \\
\text { area }\end{array}$ & $\begin{array}{l}\text { redevolpment of } \\
\text { area -development } \\
\text { of } 3686 \text { affordable } \\
\text { housing unit on ppp } \\
\text { under } \\
\text { pmay.residential } \\
\text { care home,hostels } \\
\text { for working women }\end{array}$ & $\begin{array}{l}\text { only } 5.6 \% \text { of city slum will } \\
\text { get benifited }\end{array}$ \\
\hline $\begin{array}{l}\text { physical condition of all } \\
\text { popular/heritage markets } \\
\text { are showing urban dyeing } \\
\text { symptom(façadedegradatio, } \\
\text { (surrounding } \\
\text { development),hoardings, wir } \\
\text { es,polls,encroachments) }\end{array}$ & $\begin{array}{l}\text { old } \quad \text { Gwalior-jama } \\
\text { masjid area,qilagate } \\
\text { area,lashkar(wards-40- } \\
\text { 45,50,57),thatipur }\end{array}$ & $\begin{array}{l}\text { lashkar } \\
\text { only }\end{array}$ & $\begin{array}{l}\text { revitalization of } \\
\text { markets and } \\
\text { surrounding }\end{array}$ & $\begin{array}{l}\text { old gwalior area also need } \\
\text { attention }\end{array}$ \\
\hline $\begin{array}{l}\text { no free internet access } \\
\text { facility is available except } \\
\text { Gwalior railway station } \\
\text { (Indian railways) }\end{array}$ & at whole city level & $\begin{array}{l}\text { at three } \\
\text { points }\end{array}$ & public squares & needed at more public places \\
\hline $\begin{array}{l}\text { being a regional medical } \\
\text { hub as per standards no. of } \\
\text { general hospital with bed } \\
\text { occupancies is less and no. } \\
\text { of despencieries as per } \\
\text { population }\end{array}$ & city level & & $\begin{array}{l}\text { proposal for multi } \\
\text { speciality hospital }\end{array}$ & \\
\hline
\end{tabular}




\begin{tabular}{|c|c|c|c|c|}
\hline economy & $\begin{array}{l}\text { old Gwalior-household } \\
\text { industries }\end{array}$ & & $\begin{array}{l}\text { proposal for it hub } \\
\text { and } \\
\text { buisnesscentre,skill } \\
\text { development center } \\
\text { for handloom and } \\
\text { hanicraft workers }\end{array}$ & \\
\hline public facilities & $\begin{array}{l}\text { old Gwalior and almost } \\
\text { at city level }\end{array}$ & $\begin{array}{l}18 \text { wards( } \\
\text { lashkar } \\
\text { area) }\end{array}$ & $\begin{array}{l}\text { automated public } \\
\text { toilets with water } \\
\text { atms }\end{array}$ & \\
\hline area covers & $\begin{array}{l}423.35 \text { sq.km municipal } \\
\text { area }\end{array}$ & 803 acres & $\begin{array}{ll}\text { area } & \text { based } \\
\text { proposals } & \end{array}$ & only $0.77 \%$ of city area \\
\hline population & 11.59lac & $1.02 \mathrm{lac}$ & $\begin{array}{ll}\text { area } & \text { based } \\
\text { proposals } & \\
\end{array}$ & only $8.95 \%$ of city population \\
\hline
\end{tabular}

\section{CONCLUSION}

After analyzing the city need and gaps identified its obsery that city is in need of physical and social infrastructure improvement first. proposals in smart city only cover an area or area based and one pen city city important need for servival is like-drinking water issue,cityseweragesystem,citysolidwaste managemen citytransportation,housing,slums,heritage , recreational spaces and ,i.e is basic infrastructure of city.

As per smart city guideline development the city will call as smart city which having atleast core infrastructure element like adequate water,health and education,solid waste management,sanitation,public transport,etc and other hand proposal of gwalior smart city acoording to mission strategies 'AS per which the proposed area for abd is important (as it has heritage and economic value of city). scp deals with area is in need to focused but notresolving the basic issues of city infrastrucures) which is against the smartcity guideline to become smart city.

That means only doing beautification work in a particular area will not make the city smart untill unless first we have to create/repair the city basic infrstructure fully workable and responsivebe for that as percurrent strategy of abd and pan city, we have to expand the area of concentration and money allotment of pancity more rather than abd and project on city level like seware drainage,drinking water,connectivity, walkabilty,social spaceshas to be dealed on priorityi.e reimage as strategies ,at city level project/proposal more to establish city towards smartness not only one area.

"Only dealing with an area in city without completing the basic infrastructure of city it never turn into smart city"

\section{REFERENCES}

1. Ministry of urban development (ed.): June 2015, smart city transform-nation, mission and guidelines, GOI, India.

2. Census of India (ed.):2011 district census handbook Gwalior, directorate of census operation, Madhya Pradesh, India.

3. Luard, C.E (ed.):1908, Gwalior state gazetteer volume I \& II.

4. N.S.D.C (ed.):jan.2013, district wise skill gap study of state Madhya Pradesh.

5. GDA (ed.), 2013, Gwalior development plan book, Gwalior master plan 2021, Gwalior, Madhya Pradesh.
6. Uday: water demand management strategy and implementation plan for Gwalior. water For Asian cities Programs.

7. GMC (ed.): 2017, water supply slip, Gwalior municipal cooperation, Gwalior, Madhya Pradesh.

8. GMC (ed.): 2017. Sewerage slip, Gwalior municipal cooperation, .Gwalior, Madhya Pradesh.

9. sh.suressh.s (ed.):2011.report on status of municipal solid waste management Gwalior, central pollution control board, Central zonal office, Bhopal.

10. MP tourism (ed.) 20115. annual tourism report, ministry of tourism, Madhya Pradesh. India.

11. Poverty mapping (ed.): 2005,A situation analysis of poverty pockets in Gwalior.

12. MoUD (ed.): 2014, livability standards in cities, GOI, India

13. Sudheer Singh Sikarwar 1. 2017. Analysis of Tourism Infrastructure - A Case of Gwalior City Urban Studies, IJRASET. and ISSN: 2321-9653: IC Value: 45.98: SJ Impact Factor: 6.88

14. Monika Sharma1 Padmini Pani2.Mohapatra S N: 2015 , Urban solid waste disposal site Suitability analysis using geospatial technology: a case study of Gwalior city, Madhya Pradesh. India. INTERNATIONAL JOURNAL OF ENVIRONMENTAL SCIENCES Volume 6, No 3

15. Street Design Guidelines - UTTIPEC

16. Annul Report of the Archaeological department Gwalior State (1923-24), (1924-25),( 1926-27) 